\title{
Uma proposta de sequência didática para o ensino de propagação de calor a partir do uso de incêndios florestais aplicado no Ensino Médio
}

${ }^{1}$ Hiderly da Silva Costa dos Santos; ${ }^{2}$ Roberto Ferreira dos Santos.

1,2 Universidade Federal de Roraima (UFRR)

Palavras-Chave: Propagação de Calor, Incêndios Florestais, Física, Ausubel.

\section{Introdução}

O produto educacional estará inserido numa sequência didática contemplando aulas, quais abordarão conteúdos de propagação de calor a partir do uso de incêndios florestais. Partindo da ideia que a física é a ciência que estuda e procura explicar os fenômenos da natureza, tem-se uma gama de possibilidade de explorar materiais de estudo. Assim, o presente trabalho busca explorar o conteúdo de propagação de calor em incêndios florestais, analisando os processos de: condução, radiação e convecção. O estudo de propagação de calor através de incêndios florestais pode tornase uma ferramenta relevante, em sua contextualização como práticas pedagógicas envolvendo os educandos, favorecendo o processo na perspectiva da aprendizagem significativa levando em consideração a teoria de Ausubel, estrutura cognitiva prévia ou subsunçores (MOREIRA, 2011).

\section{Métodos e Materiais}

A metodologia explorada baseia-se nas aulas sequenciais de Física, na $2^{2}$ série do Ensino médio, utilizando recurso audiovisual abordando os processos de propagação de calor, destacando estes fenômenos físicos em incêndios florestais. Para realização do plano de sequência didática é importante observar a grade Curricular ou Projeto Politico Pedagógico, dando ênfase aos métodos de processo de ensino e aprendizagem. Sendo o currículo a base para a execução de desenvolvimento do conceito do que a instituição de ensino pretende expor aos educandos. Apresentar os processos de propagação de calor no ensino da disciplina de Física, relacionandoos com o cotidiano e enfatizando os impactos ambientais que podem ser estudados nesse contexto. Isso porque este tema é de grande relevância para o estudo da Física, uma vez que é uma temática que deve ser discutida em todos os âmbitos da sociedade. As aulas sequenciais serão realizadas contemplando 6 aulas, cada uma com 1 hora, conforme o Quadro 1. A metodologia para expor os conteúdos citados será através de vídeos ${ }^{1}$ e imagens correlacionadas ao contexto, promovendo a participação dos alunos através de questionamentos e por meio do material de apoio (vídeo e imagens), motivar a participação dos educandos levando em consideração a teoria de Ausubel, que tem como base os conhecimentos prévios do aprendiz. A sequência didática está estruturada e seguirá o cronograma descrito no Quadro 1:

Quadro 1 - sequência didática na $2^{a}$ série do Ensino Médio - Física

\begin{tabular}{|c|c|}
\hline Atividades a ser desenvolvidas & Duração \\
\hline Aula I - Tema 1: Atividade de diagnósticos & 1 hora \\
\hline Aula II - Tema 2: Revisão de Conteúdos & 1 hora \\
\hline Aula III - Pré-teste & 1 hora \\
\hline Aula VI - Contextualização de mecanismo de transferência de calor: condução & 1 hora \\
\hline Aula V - Tema 3: Contextualização de mecanismo de transferência de calor: \\
Convecção e Irradiação de calor & 1 hora \\
\hline Aula VI - Tema 4: Pós Teste & 1 hora \\
\hline
\end{tabular}

Deste modo, utilizando a Termologia, abordada nos estudos físicos, é possível dialogarmos em sala de aula sobre propagação de calor: condução, convecção e radiação, fenômenos físicos que estão em nosso cotidiano, sendo destaques no período de estiagem, dando ênfase aos fenômenos físicos e danos ambientais. É importante apresentar as expressões matemáticas, utilizadas para representar conceitos físicos. Assim torna-se relevante explorar a lei da condução térmica, conhecida como lei de Fourier, a qual determina que o fluxo de calor é proporcional a temperatura, conforme Eq. (1)

\footnotetext{
${ }^{1}$ Exemplo de vídeo abordando propagação de calor: https://youtu.be/43JzOfjZpzw
} 


$$
\phi=\frac{Q}{\Delta t}=k \frac{\left(\theta_{1}-\theta_{2}\right)}{L},
$$

O que se propõe é inserir conceitos físicos através de recursos tecnológicos, com finalidade de que os educandos demonstrem interesse no assunto abordado, utilizando imagens e vídeos. Destacando os processos de propagação de calor em incêndios florestais conforme figura 1.

Figura 1- Mecanismos de transferência de calor no ambiente

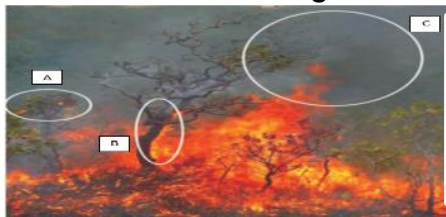

A - ramo incendiado pelo calor transferido por radiação;

B - escalada da chama no tronco principalmente por calor transferido pela condução;

C - calor ascendendo ao ambiente pela coluna de conveccão.

Fonte: Modificado de Lacerda e Cattaneo, 2008.

Durante a exposição da figura 1, serão abordados os conceitos de acordo com Manual (2010, p.34), demonstrando as principais características das formas básicas de processo de propagação de calor: Condução: é a passagem de calor por um corpo sólido em contato molecular; como por exemplo: queima de um tronco de uma extremidade até a outra. A quantidade de energia é proporcional à temperatura e à condutibilidade dos corpos. Convecção: que é a propagação por meio de gases ou fluidos. Em um incêndio florestal ocorrem duas formas de convecção: - convecção natural: movimento ascendente do ar quente devido à diferença de densidade; - convecção forçada: movimento do ar quente sob o impulso de velocidade, imposta pelo vento de superfície. A ação conjunta de ambas as formas de convecção é a causa da emissão de partículas em ignição através do ar e do preaquecimento do material à frente do incêndio. Irradiação: é a transferência de calor através do vácuo, por meio de ondas eletromagnéticas (luz visível, raios infravermelhos, entre outros).

\section{Resultados esperados}

O produto será aplicado na $2^{\underline{a}}$ série do Ensino Médio, tendo como alicerce a Base Nacional Curricular Comum - BNCC, que apresenta competências específicas de Ciências da Natureza e suas Tecnologias, dentre elas destaca-se o item 1 - "Analisar fenômenos naturais e processos tecnológicos, com base nas relações entre matéria e energia, para propor ações individuais e coletivas que aperfeiçoem processos produtivos, minimizem impactos socioambientais [...]" (BRASIL, 2017, p.540). Neste sentido, é importante impulsionar as habilidades direcionadas de acordo com as habilidades (EM13CNT102) "Realizar previsões, avaliar intervenções e/ou construir protótipos de sistemas térmicos que visem à sustentabilidade, com base na análise dos efeitos das variáveis termodinâmicas e da composição dos sistemas naturais e tecnológicos" (BRASIL, 2017, p.541). Assim, busca-se utilizar recursos tecnológicos para transpor o conteúdo de Propagação de Calor no ensino de Física, dinamizar as aulas através de imagens e vídeos que representem os processos físicos de forma que os educandos possam reconhecer e compreender no âmbito de sua vivência.

\section{Conclusão}

Através da teoria de Ausubel sendo a estrutura cognitiva prévia, espera-se que através da sequência didática utilizando recursos audiovisuais, os educandos possam obter uma aprendizagem significativa, reconhecendo os fenômenos físicos: condução, convecção e irradiação e relacioná-los com o cotidiano, reconhecendo os impactos ambientais nesse processo.

\section{Referências}

BRASIL. Base Nacional Comum Curricular (BNCC): Educação é a Base. Brasília, MEC/CONSED/UNDIME, 2017. Disponível em: <basenacionalcomum. mec.gov.br> Acesso em: 15 abr. 2019. LACERDA, F. S.; CATTANEO, A C. M. Investigação de Incêndios Florestais (Aula Teórica). In: Curso de Investigação das Causas e origens dos Incêndios Florestais - Prevfogo/IBAMA. Brasília: IBAMA, 2007.

MANUAL para formação de brigadista de prevenção e combate aos incêndios florestais. Brasília: ICBio MMA, 2010. Disponível em:<www.icmbio.gov.br/portal/images/stories/servicos/sejaumbrigadista. pdf> Acesso em: 1 jan. 2018

MOREIRA, M. A. Aprendizagem significativa: a teoria e textos complementares. São Paulo: Editora Livraria da Física, 2011. 